\title{
Roadmap to Neurosurgery - from Student to Resident
}

\author{
Mircea Vicențiu Săceleanu ${ }^{1,2}$, Aurel George Mohan ${ }^{3,4 *}$, Horia Petre Costin ${ }^{5}$, Razvan-Adrian Covache-Busuioc ${ }^{5}$, \\ Alexandru Vlad Ciurea ${ }^{6,7}$
}

'Department of Neurosurgery, County Emergency Clinical Hospital, Sibiu, Romania

2“Lucian Blaga” University, Faculty of Medicine, Sibiu, Romania

${ }^{3}$ Department of Neurosurgery, Bihor County Emergency Clinical Hospital, Oradea, Romania

${ }^{4}$ Oradea University, Faculty of Medicine, Oradea, Romania

${ }^{5}$ Student of General Medicine at "Carol Davila" University of Medicine and Pharmacy, Bucharest, Romania

${ }^{6}$ Department of Neurosurgery, Sanador Clinical Hospital, Bucharest, Romania

'Department of Neurosurgery, "Carol Davila" University of Medicine and Pharmacy, Bucharest, Romania

${ }^{*}$ Corresponding author:

Assoc. Prof. Aurel George Mohan MD. PhD

Department of Neurosurgery, Bihor

County Emergency Clinical Hospital,

Oradea, Romania

E-mail: mohanaurel@yahoo.com

\section{Rezumat}

Drumul către neurochirurgie - de la student la rezident

Neurochirurgia este o specialitate medicală care se ocupa cu diagnosticul si tratamentul patologïlor cerebrale şi ale coloanei vertebrale la sugari, copii şi adulți, având 2 componente: activitate clinică şi chirurgicală. Istoria neurochirurgiei datează din perioada preistorică, când au fost documentate primele trepanații. Cu toate acestea, volumul mare de date si tehnici pe care îl folosim astăzi fost descoperit şi inventat mulțumită contributiilor lui Joseph Lister (1827-1912), William Morton (1819-1868) şi Pierre Paul Broca (1823-1880) care au implementat reguli sistematice de antisepsie, anestezie şi, respectiv, de localizare a diferitelor zone functionale ale creierului. $\mathrm{Cu}$ toate acestea, profesori precum Harvey Cushing (1869-1939) şi Gazi Yasargil (m.1925) au reuşit să definească neurochirurgia ca specialitate chirurgicală de sine stătătoare prin îmbunătățirea semnificativă a tehnicilor chirurgicale. Mai mult, profesorul Dumitru Bagdasar este cel care a fondat neurochirurgia în România, antrenând o "echipă de neurochirurgi de aur" care s-au remarcat ca fiind primii neurochirurgi din România. În ciuda faptului că este un domeniu medical atât de nou, este necesar un volum mare de studiu teoretic şi practic. Prin urmare, un student are nevoie de dedicare şi de mult efort pentru a atinge perfecțiunea într-una dintre cele mai complexe specialități medicale, fiind nevoie de mai mult de 100 de examene şi 14.900 de ore de practică în cei 12 ani de facultate de medicina şi rezidențiat. 
Cu toate acestea, chiar dacă pare mult la început, recompensele morale ies în evidență în cele din urmă datorită contrastului semnificativ dintre starea preoperatorie şi postoperatorie a pacientului. $\mathrm{Cu}$ toate acestea, unii dintre studenți ar putea fi influențaţi negativ de familie şi prieteni prin diferite mituri conform cărora neurochirurgia este un obiectiv aproape imposibil de atins, deoarece nivelul de practică şi sacrificiile de care este nevoie sunt mult mai mari decât în alte specialități medicale. In concluzie, neurochirurgia a reuşit să depăşească misterul creierului uman şi s-a dezvoltat într-un ritm rapid, tratând în acest moment tot mai multe patologii care păreau incurabile acum 100 de ani.

Cuvinte cheie: neurochirurgie, student la medicină, educație

\section{Abstract}

Neurosurgery is a medical speciality that diagnoses and treats brain and spine pathologies of infants, children, and adults, having 2 components: clinical and surgical activities. The history of neurosurgery dates back to the Prehistoric Period when first trepanations took place. However, the extensive amount of information we use today was discovered and invented thanks to Joseph Lister (1827-1912), William T.G. Morton (1819-1868) and Pierre Paul Broca (1823-1880) who implemented systematic antisepsis rules, anaesthesia and, respectively, the localization of different areas of the brain. Nevertheless, professors such as Harvey Cushing (1869-1939) and Gazi Yasargil (n.1925) are responsible for the definition of neurosurgery as a stand-alone surgical specialty and the significant improvement of the surgical techniques. Moreover, Professor Dumitru Bagdasar (1893-1946) is the one responsible for the introduction of neurosurgery in Romania, training a "golden neurosurgeon team" who are remarked as the first neurosurgeons of Romania. Even though it is such a new medical field, a vast amount of theoretical and practical study is necessary. Therefore, a student needs dedication and lots of effort to achieve perfection in one of the most complex medical speciality, requiring more than 100 exams and over 14,900 hours of practice during the 6 years of medical school and 6 years of neurosurgical residency. Still, even if it seems a lot at first, the moral rewards stand out in the end due to the significant contrast between the preoperative and postoperative condition of the patient. Nevertheless, some of the students might be negatively influenced by family and friends through different myths that neurosurgery is a goal that is almost impossible to be achieved since the amount of practice and sacrifices it requires are a lot bigger than other medical specialities. In conclusion, neurosurgery accomplished to overcome the mystery of the human brain and developed at a fast pace. Today, neurosurgeons around the world treat more and more pathologies that seemed incurable and inoperable 100 years ago.

Key words: neurosurgery, medical student, education

\section{Introduction}

Neurosurgery is a medical speciality that deals with the diagnosis and treatment of patients with both trauma and a wide range of pathologies of the brain, spine, peripheral nervous system and cerebrovascular system. The principal activity of this speciality is both the treatment of adult patients and infants.
Moreover, neurosurgery consists of both a surgical and an investigative component, which are vital to avoid or minimize the effects of surgery. To fulfil this last component, neurosurgery needs to work with various other medical specialities in order to have access to all the necessary information before starting the surgical operation. 


\section{The History of Neurosurgery}

The history of neurosurgery dates back to the Prehistoric period, revealing skulls from the Inca Empire with procedures representing the early stage of trepanation, showing both craniotomy and cranioplasty existed ever since despite the lack of anatomical knowledge (Fig. 1).

One of the main moments of neurosurgery as a medical speciality, appeared in the twentieth century when 3 major medical discoveries became the key points of any neurosurgical intervention.

The first major innovation is represented by the invention of general anaesthesia. In 1842, the dentist William T.G. Morton (18191868) discovered the anaesthetic effects of ether, while in 1847 the obstetrician James Y. Simpson (1811-1870) introduced the use of chloroform as an anaesthetic (2). By 1895, there were produced about 750.000 doses a week in Great Britain.

The second breakthrough for all surgeons was the implementation of systematic antisepsis rules. A notable name was Ignaz Semmelweis, a Hungarian doctor and obstetrician who demonstrated that washing

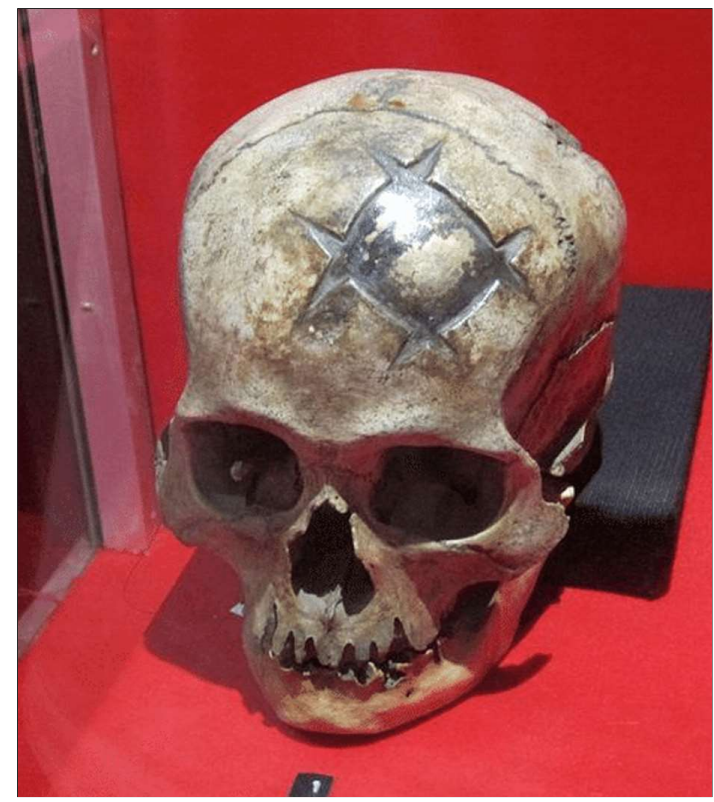

Figure 1. Gold inlay used for a cranioplasty found in Inca Empire. From the Museum of Gold, Lima, Peru (1) hands with calcium hypochlorite before birth reduced postpartum fever, which is a common obstetric complication. It is defined as a temperature of 38.7 degrees $\mathrm{C}$ or greater for the first 24 hours (3). Also, Joseph Lister, in 1867, designed an antiseptic for the treatment of wounds, which is made of Carbolic Acid (Phenol) (4).

The third discovery that played a crucial role in neurosurgery was the ability to localize specific areas of the brain. Gustav Fritsch (1838-1927) and Eduard Hetzig(1838-1907) used electrical stimulation on the precentral gyrus to define its function in wounded soldiers with traumatic brain injuries in 1870 , discovering therefore that electrical stimulation of different areas of the cerebrum caused involuntary muscular contractions of specific parts of the body (5). Moreover, they identified the brain's motor area, which is a vertical strip in the posterior region of the frontal lobe whose role is to control all the muscles of the body.

Pierre Paul Broca (1824-1880) identified in 1861 the Broca's area located in the posterior inferior frontal gyrus, which is crucial for speech production. It consists of pars opercularis, which is involved in language production and phonological processing due to its connections with motor areas of the mouth and tongue and pars triangularis, which is involved in semantic processing (6). In cases of lesions involving this area, Broca's dysphasia appears as the result, which is characterized by expressive dysphasia, when the patient understands the spoken words but cannot express himself. Another area which is involved in the cases of dysphasia is called Wernicke's area, also known as the posterior superior temporal gyrus, which is involved in speech comprehension. If lesions appear in this area, the pathology is called receptive dysphasia, when the patient cannot understand spoken words (7).

All of these discoveries had a major impact on neurosurgery, but surgical mortality was still estimated at around 50\%, making the neurosurgical practice undesirable for patients. This was going to change with the efforts of Harvey Cushing (1869-1939), who is 


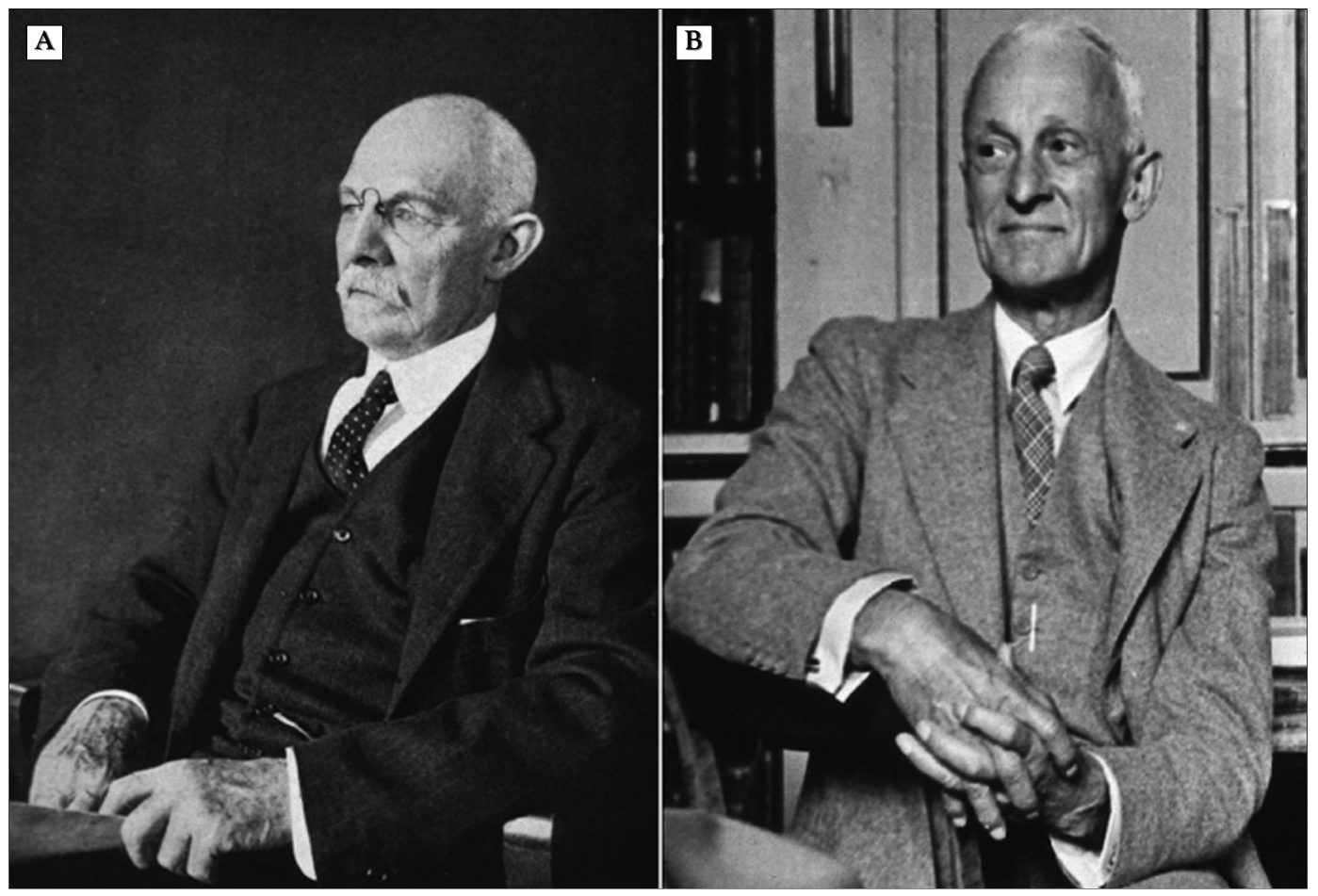

Figure 2. William Stewart Halsted "The Father of General Surgery" (A) and Harvey Cushing "The Father of Neurosurgery" (B). Both portraits licensed to the public domain

universally acclaimed as "The Father of Neurosurgery" (Fig. 2). He is renowned for his rigorously perfected technique, aimed at reducing neurosurgery-associated mortality. The postoperative mortality rate in Cushing's operations was unprecedented: $8.4 \%$ in operations of brain tumours removal and approximately $10 \%$ for pituitary surgery (8). Moreover he is responsible for the emergence of neurosurgery as a stand-alone surgical speciality.

The next breakthrough was the introduction of the operating microscope in neurosurgery. Gazi Yasargil (1925-present) is considered the "the man of the century" by the prestigious journal Neurosurgery for this remarkable progress (Fig. 3). Most modern neurosurgical procedures which involve the use of the operating microscope were originally thought, designed and implemented for the first time by him. Julius Jacobson is also famous for the development of instruments used in micro-

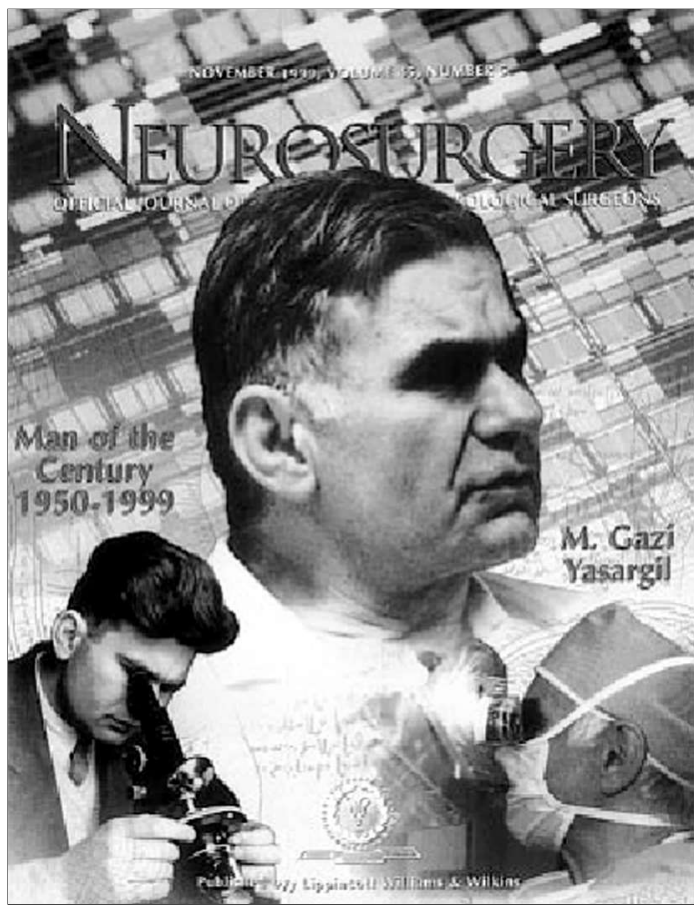

Figure 3. Professor Gazi Yasargil - Man of the century (Coverpage of Neurosurgery Nov. 1999) (10) surgery (9). 
The first CT scanner was produced by the British engineer Godfrey Hounsfield along with the physicist Allan Cormack, who received the Nobel Prize in Physiology or Medicine in 1979. Both the CT-scan and the emergence of magnetic resonance imaging (MRI) in the late 1970s provided the ability to visualise the brain and gave neurosurgeons the ability to locate tumours or perform operations in deeper and eloquent areas of the brain like never before. The first CT and first MRI applied to patients took place in 1971 and 1977 (11).

In the last 20 years, technologies such as stereotactic radiosurgery, which deliver highly concentrated radiation aimed exclusively at the tumour, saving healthy tissues, and significantly reducing side effects, have been very successful in treating patients with pituitary tumour, acoustic neuroma or meningioma. Also, the development of instruments and methods used in endoscopic surgery represented the advent of minimally invasive surgery, with a quicker recovery time and fewer scars than a craniotomy. Even more so, it is possible to use a combined approach for large tumors allowing for a partial ablation through an endonasal approach, while rest can be removed using a classic craniotomy.

Nevertheless, the surgery itself is just the tip of the iceberg when it comes about neuro- surgery, because the postoperative recovery plays an important role in the treating of a patient. Now, the recovery time after a craniotomy can take up to several weeks but due to the ongoing development of the technology. Neural plasticity represents the effort of the brain to modify its neural networks in order to cure the dysfunctions of the brain after a surgery through rehabilitation efforts. An Augmented Feedback system can monitor and give information about the entire recovery of the patient to embolden them to pursue the rehabilitation to the end (12).

The $21^{\text {st }}$ century neurosurgeon will have to integrate technology, along with advances in molecular and genetic biology. Surgery will become more and more minimally invasive until the molecular and genetic options will provide solutions for major diseases.

\section{The History of Romanian Neurosurgery}

The early history of Romanian neurosurgery starts back at the beginning of the $20^{\text {th }}$ century in 2 major University Centers, Bucharest and Iasi, where Dr. Dumitru Bagdasar (1893-1946) and Dr. Alexandru Moruzzi (1900-1957) along with their teams, succeeded in putting neurology and surgery together, in order to create neurosurgery as an independent medical speciality (Fig. $\phi$ ).
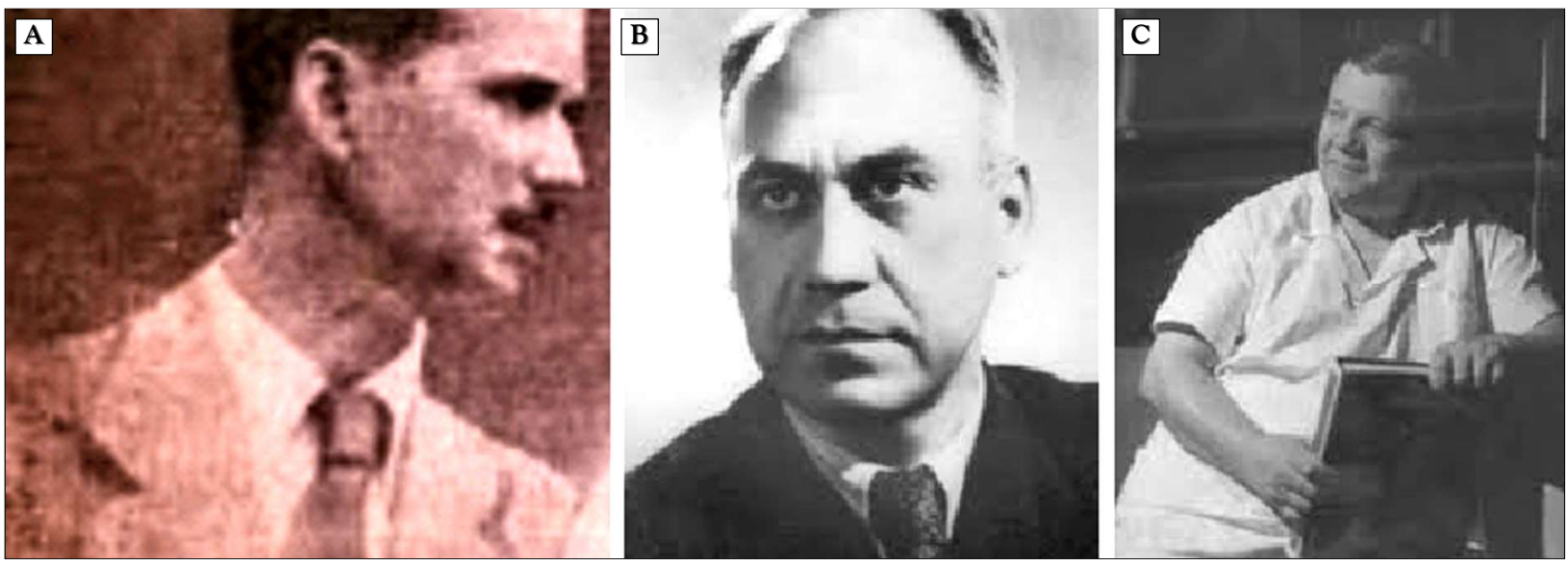

Figure 4. Prof. Dr. Alexandru Moruzzi (A), Prof. Dr. Dumitru Bagdasar (B), Prof. Dr. Constantin Arseni (C). All three portraits licensed to the public domain 
Professor Dumitru Bagdasar was trained by Professor Harvey Cushing between 1927 and 1929 at Peter Bent Brigham Hospital in Boston. After 2 years in The United States, he came back to Romania where he and his wife faced difficulties with the authorities. The first neurosurgical procedures took place at Jimbolia Hospital (1929-1931) and then at Cernauti Hospital (1931-1933). After 1933, Professor Dumitru Bagdasar and his wife returned to Bucharest, where in 1935, with the support of Professors Ion Iacobovici, Nicolae Minovici and the great histologist Ion T. Niculescu, obtained the establishment of a small neurosurgery department with only one operating room and 10 beds in Bucharest Central Hospital of Nervous Diseases (13). Thereby, this new department will become the Romanian School of Neurosurgery where Professor Dumitru Bagdasar formed the "the golden neurosurgeon team" composed of Dr. Constantin Arseni, Dr. Ion Ionescu and Dr. Sofia Ogrezeanu-Ionescu (14).

"Traité de Neurochirurgie" represents the greatest work of Professor Dumitru Bagdasar, which is published postmortem in 1948 and served as the foremost work for every Romanian neurosurgeon. However, due to a pulmonary neoplasm, Professor Dumitru Bagdasar died in 1946 and his work was continued by Constantin Arseni (1912-1994), who transformed the Department of Neurosurgery into a large Neurosurgical Clinic. The entire scientific work of the clinic was put together in eight volumes entitled "Treatise of Neurology", published between 1979 and 1981 .

Moreover, Constantin Arseni (1912-1994) (Fig. 4) founded in 1982 The Romanian Society of Neurosurgery (RSN). Since then, its objective is to support and develop all Romanian neurosurgeons both in the professional and research field, in collaboration with the Ministry of Education and Research, Ministry of Health, Academy of Medical Sciences, Universities of Medicine and other institutions. Right now, there are over 306 neurosurgeons in more than 25 medical centres in Romania, who can treat a wide range of pathologies of patients from all around the country (15).

\section{Roadmap to a Career in Neurosurgery}

The roadmap to neurosurgery is a long and difficult one, which requires a complex understanding of a vast amount of information, which may seem overwhelming at first. Also, this information must be constantly updated in accordance with discoveries and innovations both in technology and in the way a surgery must be carried out, in order to be able to treat a wide range of pathologies and traumas at the highest level. Currently, it takes 6 years of medical study at the Faculty of Medicine, followed by another 6 years of residency, which amounts over 14,900 hours of both theoretical and practical study.

In the first year, residents need to obtain the necessary knowledge for a correct and complete clinical examination of the neurosurgical patient, as well as learning to perform simple procedures such as suturing the wound and lumbar puncture.

In the second year of residency is focused on the acquisition of theoretical knowledge for emergency diagnosis of traumatic brain injury and basic surgical procedures in the surgical treatment of patients with craniocerebral trauma.

In the third year, residents learn imaging diagnosis of nontraumatic vertebro-spinal cord injuries and master the basic surgical procedures in the surgical treatment of patients with nontraumatic vertebro-medullary and peripheral nerve injuries.

The fourth year of residency is dedicated to the theoretical knowledge of clinical and imaging diagnosis of craniocerebral oncology lesions together with the basic surgical procedures to treat these pathologies.

The fifth year of residency introduces the pediatric neurosurgery and focuses on gaining both theoretical and practical knowledge to treat congenital, traumatic, oncological and infectious neurosurgical lesions in children (018 years old).

The sixth and last year of neurosurgical 
residency is dedicated to what is considered the most difficult branch of neurosurgery: neurovascular surgery. In this year, residents must acquire knowledge regarding neurovascular anatomy and hands-on experience with neurovascular pathologies such as AVM (Arteriovenous Malformation), aneurysms and cavernomas.

Thereby, at the end of the 6 years the neurosurgery the residents need to possess a wide base of theoretical training, as well as acquiring the skills and surgical experience necessary for an independent neurosurgical activity.

Neurosurgery wants to attract the best candidates who graduate from an accredited medical school. People who consider neurosurgery as a career option should have the curiosity and ability to embrace and understand the details and complexity of both the theoretical and the practical sides of this profession. Moreover, they must possess the physical and mental endurance to cope with the challenges of long and demanding training and surgeries.

Nevertheless, modern neurosurgeons need to become better and better due to the development of technology such as the modern imaging technologies which are composed of MRI (Magnetic resonance imaging), fMRI (Functional Magnetic resonance imaging), PET-CT (Positron emission tomography), DTI (Diffusion tensor imaging) and FT (Fiber tractography).

MRI and fMRI use the same principle of atomic physics, but the difference is that MRI generates $3 \mathrm{D}$ pictures of anatomical structures, whereas fMRI produces images of blood flow to certain areas of the brain in order to determine which part handles functions such as speech or movement (brain mapping), as well as discovering which part of the brain was affected due to a stroke, trauma, tumour or Alzheimer (16).

PET-CT is a type of nuclear medicine procedure that consists of a scanning device capable of detecting photons emitted by the radioactive tracer which is injected into a patient's blood. For example, in PET scans of the brain, the tracer and the glucose combine to create a radionuclide, fluorodeoxyglucose (FDG). This powerful imaging technique is used to detect conditions such as Alzheimer's disease, Parkinson's disease and tumours by showing the metabolic activity of the cells (17).

DTI uses anisotropic diffusion to estimate the axonal (white matter) organization of the brain. FT is a $3 \mathrm{D}$ reconstruction technique to assess neural tracts using data collected by diffusion tensor imaging. Both of them are used to diagnose tumours that deform the white matter and for the early detection of neurodegenerative diseases (18).

Neurosurgery has both advantages and disadvantages that must be considered when a student decides to pursue this speciality. One of these advantages is the power to help patients with various diseases and traumas that damage both their health and their social life, thus having a major moral reward through this opportunity to significantly improve patients' lives. Another advantage of this speciality is the challenging and technically diversified surgeries that any neurosurgeon goes through, this determining a constant need for selfimprovement. Also, a great advantage is represented by the numerous research opportunities in a wide area of subspecialties, which is a great opportunity to develop neurosurgery knowledge around the world.

Despite these advantages, the disadvantages exist and are mainly represented by the high degree of risk of most surgeries that a neurosurgeon must face during his career, as there can be no mistakes. David Robert Sandeman (2015) published a 15-year longitudinal study of mortality in a general neurosurgical practice, from April 1999 to March 2014, with 6006 admissions, 4255 of which had surgery (71\%). The total number of deaths during this period was 163 (2.7\% of all admissions), while the number of surgical deaths was 129 , which means $2.1 \%$ of all admissions and $3.4 \%$ of the surgical cases. Therefore, it can be seen that the mortality of neurosurgical procedures is in a continuous decline due to technological development, but according to this article, there are still 163 mournful families that need an explanation from the 
surgeon about the outcome of the surgery (19).

Also, another part of this career, that must be taken into account is the long working hours and the extensive training time that is needed to be able to perform the diversity of complex surgeries, in order to achieve a high degree of safety, both for the neurosurgeon and for the patient. Neurosurgeons operate on the brain and spine, which are different from any other organ because they host the patient's movements, speech, thoughts and personality. The level of trust that needs to be developed between neurosurgeons and their patients is unmatched and neurosurgeons thus create long-term relationships with their patients. This often requires various sacrifices that a neurosurgeon must assume, for example, the social life and family are often put in a secondary place.

The dream of becoming a neurosurgeon, which can at times seem unobtainable, may be achieved with persistence and hard work. Every individual's path to becoming a neurosurgeon is unique, but they all start with the same first step.

\section{Myth and Reality}

Taking into account the relatively short history from the recognition of neurosurgery as a medical speciality to the present, there are various myths and prejudices that exist in people's perceptions.

One of the most common prejudices related to neurosurgery is that this speciality deals only with surgeries associated with brain pathologies. However, most neurosurgical procedures involve the treatment of spine disorders. Therefore, a neurosurgeon must understand the complex relationship between the brain and spine.

The second confusion that occurs in almost every patient's mind is that he may consider going to a neurosurgeon only when surgery is immediately needed. However, neurosurgeons are not simply surgeons. Their role in diagnosing and treating the disease is much more extensive than performing surgery. Neurosurgeons are frequently called to consult with other specialists due to their extensive knowledge. They are the most qualified to establish the correct treatment plan for a patient, which may include surgery only as a last resort. Therefore, contrary to this common confusion, a neurosurgeon is the first specialist a patient should see to ensure proper diagnosis and treatment.

Another major impediment in deciding to pursue a career in neurosurgery is the influence of people around the student, who is often told by both family and friends that neurosurgery is a goal that is almost impossible to be achieved, due to the long study and training period. As with all advice, it must be viewed both objectively and introspectively. Indeed, neurosurgery is unique compared to other medical specialities, as it requires that anyone in this branch of medicine to strive towards perfection. This idea is underlined both by the small number of neurosurgery professors in Romania, where there are only 7 university professors in total and by the small number of neurosurgeons internationally, of approximately 49,950 (20). T. Odell et al. (2019) found that women represent only $12 \%$ of neurosurgeons in The United States and Canada (21), due to the difficulty of this speciality and the high number of sacrifices needed when it comes to family necessary to become a neurosurgeon. All in all, this discouraging discussion should arouse in a student's mind a desire for ambition and continuous improvement, since in neurosurgery there are some of the biggest and fastest professional satisfactions compared to other branches of medicine, thus having the opportunity to change a patient's life in a profoundly positive way.

\section{Conclusion}

All things considered, neurosurgery can be seen as a unique medical speciality, offering extraordinary satisfactions and at the same time disadvantages.

Even though the desire to know the human brain has been a curiosity for mankind since ancient times, the evolution of neurosurgery 
was not possible until the late nineteenth century, when the invention of the first devices designed to provide more information about a scientific area hidden in mystery until then and major discoveries in antisepsis have managed to form neurosurgery a medical speciality worthy of study and research.

It is so complex that even so far, we lack much information that will be discovered with the help of technology that is evolving at such a fast pace that anything that seems to belong to the field of the future will soon be a normality in the life of any neurosurgeon.

Moreover, step by step, the public at large will have a much more objective and clearer vision of how this new branch of medicine should be perceived, decreasing the prejudice that neurosurgery is a last resort for any patient.

In this way, people will get rid of the constant fear and the wrongly formulated idea that presents a neurosurgeon as an ordinary surgeon. The world will better understand the high level of training of any doctor who practices this speciality and will realize that the duties of such a person are not limited to surgery but extend to taking various prophylactic measures to avoid as much as possible a surgery that can present high risks for the patient.

Therefore, neurosurgery aims to overcome the last obstacle that stands in the way of complete knowledge of the human body and how it works, managing to treat at this time major diseases that seemed incurable 100 years ago. Through innovations that seem at this moment unfeasible, we will be able to find out in the future more and more useful information in order to make neurosurgery the closest medical speciality to perfection.

\section{Disclaimer}

The authors have no conflicts of interest to declare.

\section{References}

2. Al Awar 0, Sustickas G; Landmarks in the History of Traumatic Head Injury. 2017

3. Dabaliz AA, Bause GS; How chloroform anesthesia reached Lowell, Massachusetts: From Simpson`s pamphlet to Gladwin`s advertisement. J. Anest. Hist. 2020, 6(3):156-157

4. Kadar N, Romero R, Papp Z; Ignaz Semmelweis: the "Savior of Mothers": On the 200th anniversaro of his birth. Am J Obsetet Gynecol. 2018; 219(6):519522

5. Tan SY, Tasaki A; Joseph Lister (1827-1912): Father of antisepsis, Singapore Med J. 2007;48(7):605-606

6. Koehler PJ; Eduard Hitzig`s experiences in the Franco-Prussian War (18701871): The case of Jeseph Masseau, J Hist Neurosci, 2021. 21(3):250-262

7. Jay V; Pierre Paul Broca, Arch Pathol Lab Med. 2002;126(3):250-251

8. Ferguson SD, McCutcheon IE; Surgical Management of Gliomas in Eloquent Cortex, Prog. Neuro. Surg. 2017;39:159-172

9. Sundararaman LV, Desai SP; The Anesthesia Records of Harvey Cushing and Ernest Codman, Anest. Analg. 2018;126(1):322-329

10. Kobayashi S, Matsushima T, Sakai T, Matsushima K, Bertalanffy H, Rutka JT; Evolution of microneurosurgical anatomy with special reference to the history of anatomy, surgical anatomy and microsurgery: historical overview, Neurosurg Rev. 2021 Jul 7. doi: 10.1007/s10143-021-01597-z. Online ahead of print.

11. Tew Jr. JM, Yasargil G. Neurosurgery`s Man of the Century, Neurosurgery. 1999:45(5):1010-1014

12. Nicholls M; Sir Godfrey Newbold Hounsfield and Allan M. Cormack, Eur. Heart. J. 2019;40(26):2101-2103

13. Fereche $\mathrm{O}$, Moldoveanu $\mathrm{A}$, Cinteza D, Toader $\mathrm{C}$, et al; From neuromotor command to feedback a surbey of techniques for rehabilitation through altered perception, 2015 E-health and bioengineering conference (EHB), 2015, $1-4$

14. Dumitrascu DL, Shamp MA, Kyle RA; Dumitru Bagdasar - father of Romanian neurosurgery, Mayo Clin. Proc. 1996. 71(1):31

15. Ciurea AV, Moisa HA, Mohdan D; Sofia lonescu, the first woman neurosurgeon in the world, World Neurosurg. 2013;80(5):650-653

16. Mohan AG, Saceleanu MV, Marinescu AA, Popoescu M, Ciurea AV: Neurosurgery in Romania in the centenary of the Great Union (1918-2018), Rom. J. Morphol. Embryol. 2018;59(4):1299-1303

17. Logothetis NK; What we can do and what we cannot do with fMRI, Nature. 2008;435(7197):869-878

18. Ehman EC et al; PET/MRI Where might it replace PET/CT, J. Magn. Reason. Imaging. 2017;46(5):1247-1262

19. Assag Y, Pasternak 0; Diffusion tensor imaging (DTI)Obased white matter mapping in brain research: A review, J. Mol. Neurosci. 2008;34(1):51-61

20. Sandeman DR; 15 -year longitudinal study of mortality in a general neurosurgical practice, Br. J. Neurosurg. 2015; 29(4):500-504

21. Mukhopadhyay S, Punchak M, Rattani A, Hung YC, Dahm J, Faruque S, et al. The global neurosurgical workforce: a mixed-methods assessment of density and growth, J. Neurosurg. 2021;130(4):1142-1148

22. Odell T, Toor H, Takayanagi A, Zampella B, Siddiqi J, Jalal S, et al. Gender disparity in academic neurosurgery. Cureus. 2019;11(5):e4628. 